\title{
Employee Performance Measurement in Teleworking Using Balanced Scorecard
}

\author{
Sunu Sugi Arso1, Sfenrianto Sfenrianto², Mochamad Wahyudi ${ }^{3}$ \\ ${ }^{1}$ PT. Mitra Intergrasi Informatika, Indonesia \\ ${ }^{2}$ Information Systems Management Department, BINUS Graduate Program - Master of Information Systems \\ Management, Bina Nusantara University, Indonesia \\ ${ }^{3}$ Master of Computer Science - Postgraduate Programs STMIK Nusa Mandiri, Indonesia
}

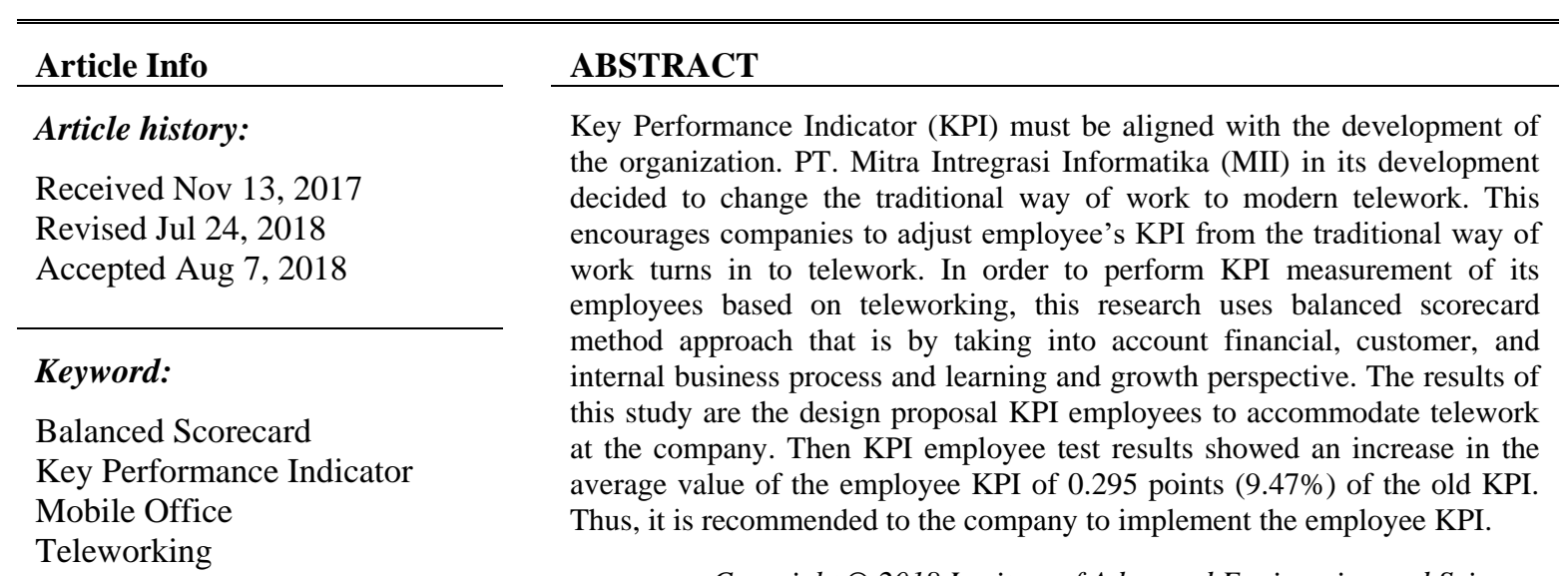

Copyright () 2018 Institute of Advanced Engineering and Science. All rights reserved.

\section{Corresponding Author:}

Sfenrianto Sfenrianto,

Information Systems Management Department,

BINUS Graduate Program - Master of Information Systems Management,

Bina Nusantara University, 11480, Jakarta, Indonesia.

Email: sfenrianto@binus.edu

\section{INTRODUCTION}

Research shows that telework generally increases job performance and productivity [1]. Telework is a model or way of working where employees gain the flexibility of working in terms of place and time of work with the help of telecommunication technology. This new way of working can be mutually benefitting between employers and employees by decreasing organizational and labor costs while increasing positive work-life balance. These mutual benefits may increase job satisfaction and organizational commitment [2].

Companies gain many benefits from employing teleworkers. For example: The technologies such as: mobile [3]-[5], mobile office [6], [7], and internet [8]-[10] are used to improve the productivity and efficiency of mobile workers. Then, employing teleworkers reduces the cost of overhead for office space [11], commute times [12], traffic, absenteeism [13], turnover rates [14]. Companies that allow teleworking also project a state-of-the-art image by employing modern work practices [15]. Finally, teleworking benefits employees by giving them flexibility and freedom to work from wherever and whenever they want while creating satisfaction both on the job and at the home [11], [14].

Telework has been widely applied in various companies, one of which is PT. Mitra Integrasi Informatika (MII). The Company had been implemented telework for about 4 years. The purpose of applied telework is to maximize the regulation of the use of mobile employees work time, both inside and outside the office. With the set policy and telework system working terms, then employees can perform tasks and jobs optimum. However, since teleworking had been applied, there has been no adjustment to key employee performance indicator (KPI) measurement.The company does not yet have KPI employee measurements 
relating to the implementation of telework. In addition, the current KPI measurement does not use the balanced scorecard method. This study is to provide companies with a proposal on KPI employee measurement design using balanced scorecards for mobile employees.

Kaplan and Norton find performance measurement by considering four aspects: financial, customer, internal business process and learning and growth [16]. The approach is the Balanced Scorecard which provides a comprehensive framework that can translate the company's strategic objectives into overall company performance measurement. Balanced Scorecard is one tool that allows management to track the results of financial performance and simultaneously oversee the progress of the company's growth in general.

In performance measurement, it is very important to make the selection of appropriate performance measures directly related to the company's strategic objectives. The process of determining the measurement of KPI must be objective. To make it easier to remember using the term SMART [17]. Specific is several determinants that must exist in the size to be applied and must be specific. Measurable means it should be measurable by using appropriate measurement indicators to evaluate success, review, and future corrective actions. Achievable is to determine the objectives that can be achieved. Realistic target achievement will usually be more challenging, but less challenging if the likelihood of success is small. Time-based means the period specified to make an assessment of business achievement. Thus, the study have recommended developing KPIs using a balanced scorecard [18].

\section{RESEARCH METHOD}

\subsection{Performance Measurement Based on Balanced Scorecard (BSC)}

BSC is a performance evaluation system made especially for 12 companies in America [18]. The cardinal purpose of BSC is to replace traditional performance system focusing on assessing one single financial index to obtain more adequate and comelier performance evaluation model. This concept gets out of the traditional performance evaluation model merely based on financial accounting. For BSC, financial perspective is still the core of performance evaluation but the other four perspectives such as customer, industrial process, learning and growth of employees should be included in as well to enable the performance evaluation method to be more balanced and also having the effectiveness of encouraging organizations.

Financial perspective.This perspective reflects the past operating performance of a company including the achievement of setting up a financial target and the implementation of executing strategies. Though this, it could be seen whether organizations gain growth, return and risk control from operating strategies. The indices of evaluation usually contain operating income, operating costs, return on investment, net profit rate, cash flows, etc.

Customer perspective. For emphasizing the market segmentation of customers, organizations should utilize their intrinsic advantages and resources to distinguish the differences with their competitors. The core measurements include market share ratio, acquirement of customers, continuation of customers, customer satisfaction, and profitability of customers.

Internal process perspective. In this perspective, it addresses the internal operating process of organizations that have to follow a plan of operating strategies made by them and also do their best to achieve the expectations of customers and shareholders. The whole process is starting from understanding customer requirements, innovation process, operating process, after-sales service and finally achieves customer requirements to establish evaluation indices through all these.

Learning and growth perspective. If organizations want to have sustainable operation and development, they should rely on continual innovation and growth. Companies should persist on some principles such as enhancing the abilities of employees, the performance of information systems, encouragement, the consistence of authority, etc. This perspective includes three main core evaluation criteria and they are satisfaction of employees, continuation of employees, and productivities of employees. Organizations should establish performance evaluation indices through these three criteria.

Then, the study use existing traditional KPI set by the company to measure employee performance. The initial stage in conducting this research is identifying the existing problems. Where the problem identified at the beginning is that the company does not have a productivity measurement model related to the implementation of mobile office policy in the corporate environment. Where the company does not know for sure the successful implementation of mobile office that supports employee productivity.

Then on next stage the author will first perform an evaluation of the current model. The current KPI measurements do not involve measuring the use of mobile office technology. The current measurement is (1) Target Gross Profit is target achievement in the current year recorded in the SAP system; (2). Personal development: Certification on product / solution training and solution Presentation is target of certification of product training / training solution followed up to fiscal year of the current year, and conduct Solution Presentation (conceptual IT related material); (3) Solution selling is target selling solution future business 
plan to customer;(4) Target proposals related to improvement or development, or a new thing that has value added creatively in all aspects of work.

Then, interview with some Board of Directors. The formulation of strategic maps has been conducted several times interviews with management. Materials discussion of interviews surrounding the vision and mission, policies that exist within the organization. The formulation of the strategic map is expected to assist in determining the targets that exist in the Balanced Scorecard.

\subsection{Strategic Map}

The process of formulating a strategy map Key Performance Indicator, in general, must be in line with the vision and mission of the company. In accordance with the perspective of the Balanced Score Card described in study [16], the Company's vision and mission must develop into a corporate strategy that must be formulated into measures and objectives consistent with the company's strategy.

Strategic mapping is created by the organization. A strategy map is a simple graphic that shows a logical, cause-and-effect connection between strategic objectives (shown as ovals on the map). Generally speaking, improving performance in the objectives found in the Organizational Capacity perspective (the bottom row) enables the organization to improve its Internal Process perspective (the next row up), which, in turn, enables the organization to create desirable results in the Customer and Financial perspectives (the top two rows). Figure 1, shows the developed strategic map of MII. Start from bottom is learning and growing perspective factor that will impact internal process perspective. The internal process perspective will impact on customer satisfaction. And customer satisfaction at the end will result financial perspective that is business impact.

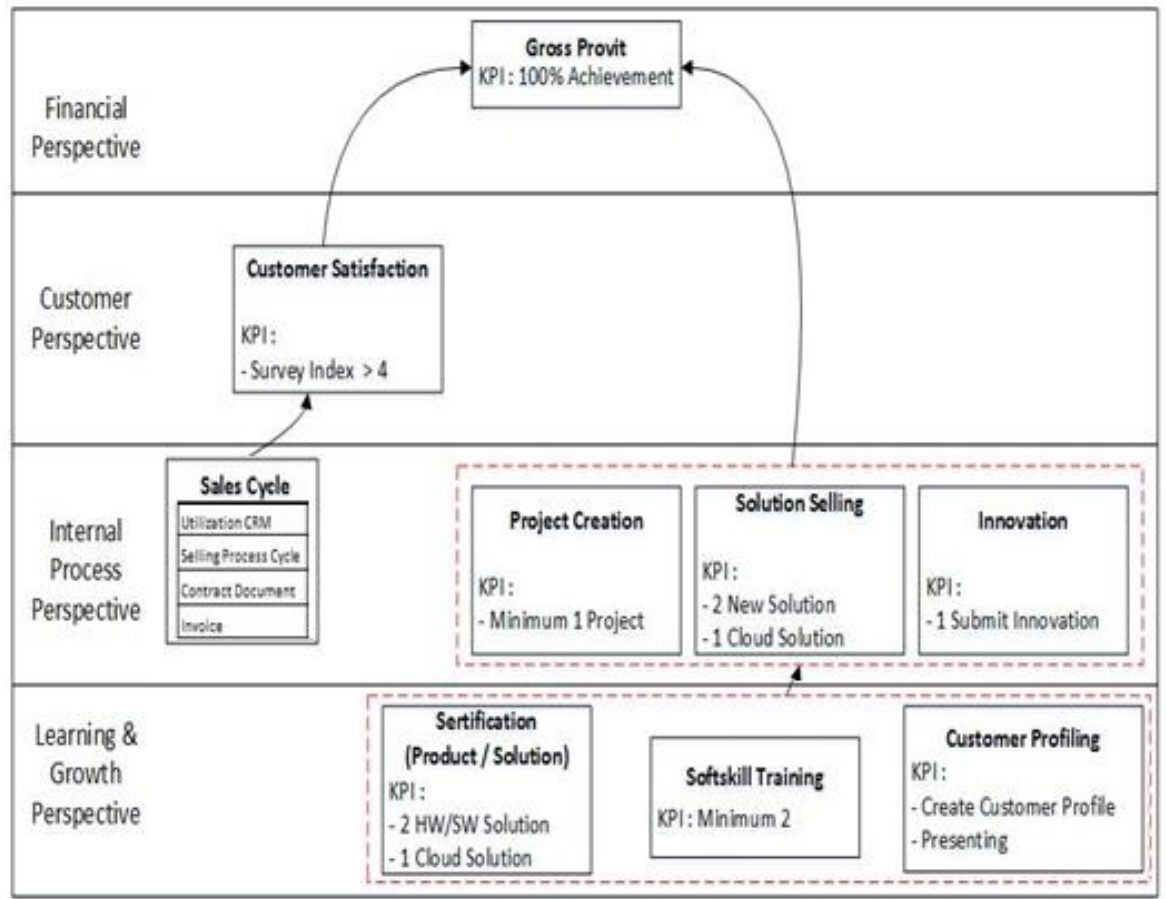

Figure 1. The result of formulating strategy map

Based on Figure 1 the strategic map detailed describes financial perspective, customer perspective, internal process perspective and learning and growth perspective. Financial perspective of gross profit is the main target of employee performance measurement. The measured target is Gross Profit sales whose calculations are withdrawn from the SAP system. Gross Profit in question is the value resulting from the sale after deducting the costs incurred.

Customer perspective is a measure of how a service provided by a company meets or exceeds customer expectations. It is important because it provides marketers and business owners with the metrics they can use to improve customer satisfaction. Thus, customer satisfaction survey is a way to get customer 
feedback. From the answers to the set of questions the survey will know the rating of sales service (ranting index).

Internal process perspectives are (1) Sales Cycle is the part where employees are expected to be able to process sales cycle efficiently. There are several variables, namely: Utilization CRM, selling process cycle, contract document, and invoice. As expected with the application and support of this mobile office policy business process will be more efficient; (2) Project Creation is creating new opportunities is the target of this section. Where employees with self-development briefings both soft skill and certification of product and solution are expected to create new opportunities. No need to wait for the needs of customers, employees are expected to be able to dialogue with customers, provide new views for an opportunity to be made; (3) Solution Selling is the section aims for employees able to sell solutions that in the current year become a mainstay or become a trend or even a future business plan; and (4) Innovation is a target that is not only given to employees who are in Directorate of Corporate Sales but also applies to all employees. Proposed criteria refer to: 1 . focus on one area, 2. extensive impact, and 3. Improve competitiveness for the company.

Learning and growth perspective are (1) Certification on Product/Solution is developed technical capabilities to support day-to-day tasks and responsibilities, especially in matters relating to supervision and management of employees. The measure used is the amount of training gained to improve the competence; (2) Soft Skill Training is that employees have the ability to lead to self-development or the ability to manage tasks, such as managerial skills, communication skills, leadership, networking, or personal development. In this case, employees have the managerial skills used to negotiate, lead subordinates and also the ability to make decisions that will ultimately improve their ability to resolve problems; (3) The benchmark for strategic objectives of enhancing managerial skills is the amount of managerial training the employees get; and (4) Customer Profiling is to get to know the customer better, every employee needs to create a customer profile. The customer profile is used to create a proper understanding of customer behavior and characteristics.

\section{RESULTS AND ANALYSIS}

Table 1 show a proposed KPI for teleworking based onstrategic map and each perspective of balanced scorecard. The KPI will be implemented in the MII.

Table 1. Proposed KPI for teleworking

\begin{tabular}{|c|c|c|c|c|c|}
\hline Perspective & Strategic Objective & KPI & $\begin{array}{c}\text { Unit of } \\
\text { Measurement }\end{array}$ & Target & Initiatives \\
\hline Financial & $\begin{array}{l}\text { Gross Profit (End } \\
\text { Year) }\end{array}$ & GP Target vs.GP Actual & $\%$ & 100 & $\begin{array}{l}\text { Monthly progress evaluation } \\
\text { Pipeline review }\end{array}$ \\
\hline Customer & $\begin{array}{l}\text { Increase customer } \\
\text { satisfaction }\end{array}$ & $\begin{array}{l}\text { Customer satisfaction } \\
\text { index }\end{array}$ & Index & $>4$ & $\begin{array}{l}\text { Increase response to customer } \\
\text { Increase quality of service } \\
\text { Follow up occurred issue }\end{array}$ \\
\hline Internal & Sales Cycle: & & & & \\
\hline \multirow[t]{7}{*}{$\begin{array}{l}\text { Business } \\
\text { Process }\end{array}$} & Utilization CRM & $\begin{array}{l}\text { Data Accuracy (Pipeline } \\
\text { Opportunity) }\end{array}$ & $\%$ & 80 & $\begin{array}{l}\text { Regularly review and input data on } \\
\text { CRM }\end{array}$ \\
\hline & $\begin{array}{l}\text { Selling Process } \\
\text { Cycle }\end{array}$ & $\begin{array}{l}\text { Max } 1 \text { week SO ready } \\
\text { after PO }\end{array}$ & Time & & Update as soon as receive PO. \\
\hline & Contract Document & $\begin{array}{l}\text { Contract Doc ready } \\
\text { before Project KOM }\end{array}$ & $\%$ & & $\begin{array}{l}\text { Submit draft contract as soon as } \mathrm{PO} \\
\text { received }\end{array}$ \\
\hline & Invoice & $\begin{array}{l}\text { No missed invoice on } \\
\text { committed billing }\end{array}$ & $\%$ & & Collect BAST on time \\
\hline & Project Creation & Number of project & Number & 1 & $\begin{array}{l}\text { Have engagement with customer and } \\
\text { principal to create project }\end{array}$ \\
\hline & Solution Selling & $\begin{array}{l}\text { Number of solution } \\
\text { selling }\end{array}$ & Number & 3 & $\begin{array}{l}\text { Create new demand by having } \\
\text { engagement with customer and } \\
\text { principal to create new solution to be } \\
\text { implemented }\end{array}$ \\
\hline & Innovation & $\begin{array}{l}\text { Number of submitted } \\
\text { innovation }\end{array}$ & Number & 1 & $\begin{array}{l}\text { Develop idea for innovation to } \\
\text { improve business }\end{array}$ \\
\hline \multirow[t]{3}{*}{$\begin{array}{l}\text { Leaning \& } \\
\text { Growth }\end{array}$} & $\begin{array}{l}\text { Improve staff } \\
\text { capabilities }\end{array}$ & Number of Certification & Number & 3 & $\begin{array}{l}\text { Engagement with product team and } \\
\text { presales for knowledge update } \\
\text { Requesting certification }\end{array}$ \\
\hline & & Soft Skill Training & Number & 2 & $\begin{array}{l}\text { Engagement HR for soft skill } \\
\text { development }\end{array}$ \\
\hline & & Customer Profiling & Number & & $\begin{array}{l}\text { Requesting soft skill training to HR } \\
\text { Ccustomers profile collaborate with } \\
\text { presales, product and delivery team. }\end{array}$ \\
\hline
\end{tabular}




\subsection{Simulating KPI}

To conduct the simulation of KPI, 10 respondents were involved. The simulation mechanism is to ask the respondents to review their respective KPIs within the evaluation period of 2017. The following is the simulation results with the new KPI design with the data of the respondents involved. Where each cell is filled with data coming from the respondent. Then the data is calculated to generate KPI from each responder as described on Table 2. For example on KPI target 1 to 5, respondent 1 simulation on financial (Fin) perspective gets 3 point on $30 \%$ weight, on customer satisfaction (Cust) gets 3 point on 15\% weight, on sales cycle (BP-SC) get 4 point on $5 \%$ weight, on process cycle (BP-PC) gets 4 point on $10 \%$ weight, on selling solution (BP-SS) get 4 point on $10 \%$ weight, on innovation (BP-IN) gets 3 point on $15 \%$ weight, on technical certification (LG-TC) gets 2 point on 5\% weight, on soft skill (BP-SK) gets 4 point on $5 \%$ weight, and on customer profiling (LG-CP) gets 3 point on 5\% weight. The total KPI calculation of this respondent is 3.3.

Table 2. New KPI Design Simulation

\begin{tabular}{|c|c|c|c|c|c|c|c|c|c|c|}
\hline Respondents & $\begin{array}{l}\text { Fin } \\
30 \%\end{array}$ & $\begin{array}{l}\text { Cust } \\
15 \%\end{array}$ & $\begin{array}{c}\text { BP-SC } \\
5 \%\end{array}$ & $\begin{array}{c}\text { BP-PC } \\
10 \%\end{array}$ & $\begin{array}{c}\text { Target } \\
\text { BP-SS } \\
10 \%\end{array}$ & $\begin{array}{c}\text { BP-IN } \\
15 \%\end{array}$ & $\begin{array}{c}\text { LG-TC } \\
5 \%\end{array}$ & $\begin{array}{c}\text { LG-SK } \\
5 \%\end{array}$ & $\begin{array}{c}\text { LG-CP } \\
5 \%\end{array}$ & $\begin{array}{l}\text { KPI } \\
100 \%\end{array}$ \\
\hline Respondent 1 & 3 & 3 & 4 & 4 & 4 & 3 & 2 & 4 & 3 & 3.3 \\
\hline Respondent 2 & 3 & 3 & 2 & 3 & 2 & 2 & 4 & 2 & 2 & 2.7 \\
\hline Respondent 3 & 3 & 3 & 3 & 2 & 3 & 3 & 3 & 3 & 2 & 2.9 \\
\hline Respondent 4 & 4 & 3 & 2 & 3 & 5 & 3 & 5 & 5 & 5 & 3.8 \\
\hline Respondent 5 & 3 & 3 & 3 & 3 & 3 & 2 & 3 & 3 & 3 & 2.9 \\
\hline Respondent 6 & 4 & 4 & 3 & 3 & 4 & 3 & 4 & 4 & 4 & 3.7 \\
\hline Respondent 7 & 3 & 3 & 3 & 3 & 3 & 2 & 3 & 3 & 5 & 3.0 \\
\hline Respondent 8 & 5 & 5 & 5 & 5 & 5 & 3 & 5 & 5 & 5 & 4.7 \\
\hline Respondent 9 & 3 & 4 & 4 & 4 & 4 & 3 & 5 & 4 & 2 & 3.5 \\
\hline Respondent 10 & 4 & 3 & 5 & 5 & 3 & 3 & 5 & 5 & 5 & 3.9 \\
\hline
\end{tabular}

\subsection{Comparing Old KPI and New KPI}

Refer to old KPI that only calculation of financial (Fin), technical skill (TC), selling solution (SS), and innovation (IN). This is defer from the new KPI for teleworking. To prove that there is an improvement on the new KPI from the old KPI, the old KPI was simulated as well. The result of the old KPI simulation is show on Table 3 . Then in Table 4 show the comparison between old KPI result and new KPI.

Table 3. Old KPI Simulation Respondents

\begin{tabular}{lrrrrr}
\hline \multirow{2}{*}{ Respondents } & Fin & TC & SS & IN & KPI \\
& $40 \%$ & $30 \%$ & $15 \%$ & $15 \%$ & $100 \%$ \\
\hline Respondent 1 & 3 & 2 & 2 & 2 & 2.4 \\
Respondent 2 & 3 & 2 & 2 & 2 & 2.4 \\
Respondent 3 & 3 & 3 & 1 & 1 & 2.4 \\
Respondent 4 & 4 & 2 & 5 & 3 & 3.4 \\
Respondent 5 & 3 & 3 & 3 & 2 & 2.9 \\
Respondent 6 & 3 & 4 & 4 & 3 & 3.5 \\
Respondent 7 & 3 & 3 & 3 & 2 & 2.9 \\
Respondent 8 & 5 & 5 & 5 & 3 & 4.7 \\
Respondent 9 & 3 & 5 & 3 & 3 & 3.6 \\
Respondent 10 & 4 & 2 & 3 & 3 & 3.1 \\
\hline
\end{tabular}

Table 4. Comparison between Old and New KPI Respondents

\begin{tabular}{lcc}
\hline Respondents & Old KPI & New KPI \\
\hline Respondent 1 & 2.4 & 3.25 \\
Respondent 2 & 2.4 & 2.65 \\
Respondent 3 & 2.4 & 2.85 \\
Respondent 4 & 3.4 & 3.75 \\
Respondent 5 & 2.85 & 2.85 \\
Respondent 6 & 3.45 & 3.7 \\
Respondent 7 & 2.85 & 2.95 \\
Respondent 8 & 4.7 & 4.7 \\
Respondent 9 & 3.6 & 3.5 \\
Respondent 10 & 3.1 & 3.9 \\
Average & 3.115 & 3.41 \\
\hline
\end{tabular}


Based on Table 4, result comparison of the average value between the old KPI and new KPI, there is an increase of 0.295 points $(9.47 \%$ ). Figure 2, shows result comparison of old KPI and new KPI. It can be seen that from 10 respondents, 8 of them experienced an increase in KPI, only 2 respondents did not experience an increase in KPI. We can conclude that $80 \%$ of respondents experienced an increase in KPI.

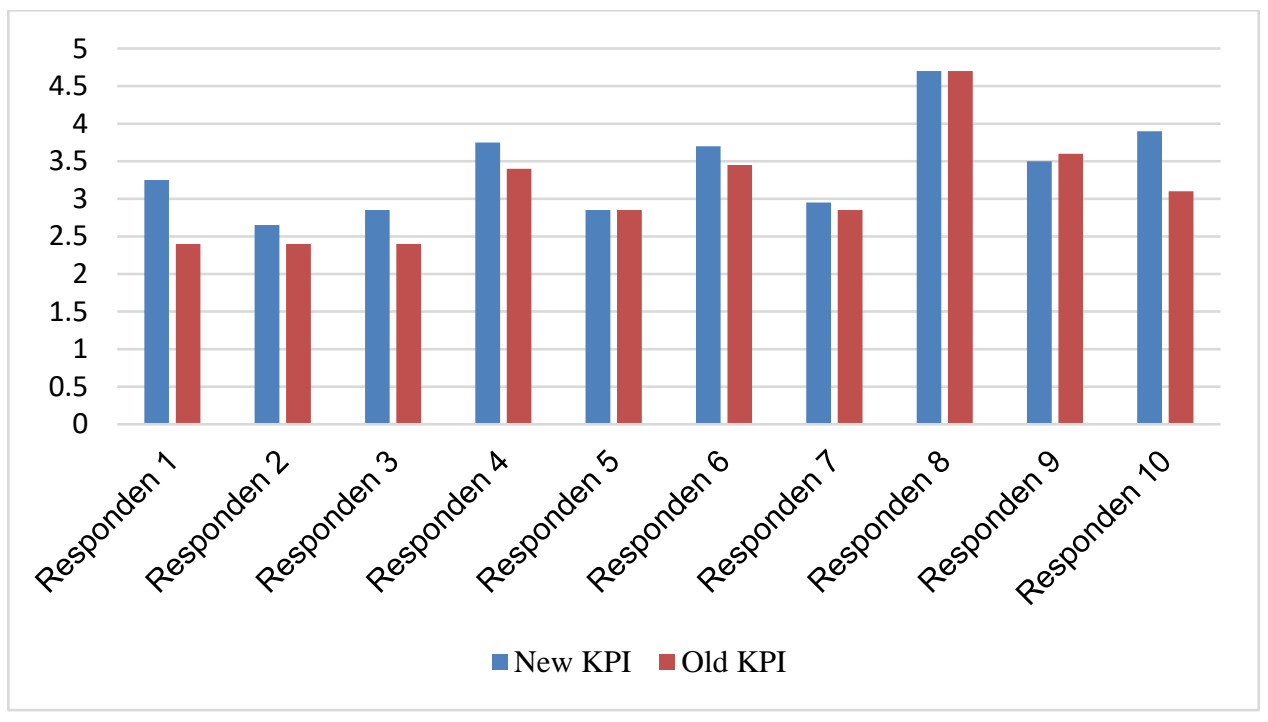

Figure 2. Result Comparison of Old KPI and New KPI

\section{CONCLUSION}

The old KPI is not measuring teleworking of the employee. However, the new KPI prosed using balanced scorecard perspective. The study proposes the new KPI using balanced scorecard perspective, more objective measurements based on financial, customer, internal business process, and learning and growth perspectives. Designing KPI using balanced scorecard, start from aligning strategy map and KPI. Proposed KPI had been simulated on 10 respondents, when compared to old KPI there is 0.295 increments equal to 9.47\%. We recommend Organization which has employee that works in teleworking way can surely apply this measurement model. For the future research, it is needed to adopt another approach such as: six sigmaand other approaches.

\section{REFERENCES}

[1] Hill, E.J., and Weiner, S.P., Work/life balance policies and program in J.E. Edwards, J. C. Scott, N.S. Saju (Eds), The humand resources program-evaluated handbook.Thousand Oaks, CA: Sage Publications. pp. 447-468, 2003.

[2] Zimmerman, J., Work-Life Balance and Teleworking: Developing and Testing a Teleworker Performance Model. Dissertation Manuscript, Northcentral University, Arizona. 2017.

[3] Yongbin Z, Li Y, and Junsheng L., "Mobile Internet Information Security Analysis and Countermeasures", TELKOMNIKA Telecommunication, Computing, Electronics and Control, vol.14 (3A), pp. 333-337, 2016.

[4] Khalil A., "Mobile Learning Technologies", International Journal of Electrical and Computer Engineering (IJECE), vol. 7(5), pp. 2833-2837, 2017.

[5] Morrison, J. Shrestha, N.R. Hayes, B, and Zimmerman M., "Mobile Phone Support for Rural Health Workers in Nepal through 'Celemedicine", Journal of the Nepal Medical Association (JNMA),vol. 52(191), pp. 538-42, 2013

[6] Yim, S., and Shin, M., "Effects of system quality and information quality on the use and job performance of an enterprise mobility solution for a mobile office with a consideration of task mobility and task interdependence as control variables", Asia Pacific Journal of Information Systems, vol. 24, pp. 115-140, 2014.

[7] Koo, S.H., Lee, J.E, and Shin, M.S., "The Effect of Mobile Office Service Quality Factors on the User Satisfaction: Focused onUsage and Job Characteristics", Korea Society of IT services Journal, vol. 11(2), pp. 1-16, 2012.

[8] Moody, G.D., and Siponen, M., "Using the theory of interpersonal behavior to explain nonwork-related personal use of the Internet at work", Information \& Management, vol 50, pp. 322-335, 2013

[9] Jesús, A.C., Elizabeth, A.G., Mario A.F., and Patricia, P.R., "Internet Prospective Study", Bulletin of Electrical Engineering and Informatics, vol. 6(3), pp. 235-240, 2017.

[10] Amine, R., Abdelmajid, O., "Internet of Things: Surveys for Measuring Human Activities from Everywhere", International Journal of Electrical and Computer Engineering (IJECE), vol. 7(5), pp. 2474-2482, 2017.

[11] Divol, R., and Fleming, T. The evolution of work. One company's story. McKinsey Quarterly 4. pp.111-115, 2012. 
[12] Eversole, B.A.W., Venneberg, D.L., and Crowder, C.L., "Creating a flexible organizational culture to attract and retain talented workers across generations", Advances in Developing Human Resources, vol. 14, pp. 607- 625, 2012.

[13] Glass, J.L., and Noonan, M.C. "The hard truth about telecommuting", Monthly Labor Review, vol. 135. pp. 38-45, 2012.

[14] Irby, C.M. “All in a day’s work: Overcoming telework challenges”, Monthly Labor Review. Pp. 1-2, 2014.

[15] Pyöriä, P. "Managing telework: Risks, fears and rules”, Management Research Review”, vol. 34(4), pp. 386-399, 2011.

[16] Kaplan, R.S., and Norton, D. "The balanced scorecard measures that drive performance". Harvard Business Review. vol. 70(1), pp. 71-79, 2007.

[17] Robert, L.B., Use S.M.A.R.T. goals to launch management by objective plan. Available from: http://www.techrepublic.com/article/use-smart-goals-to-launch-management-by-objectives-plan/5683094/.

[18] Davis, Tim R.V., "Developing an employee balanced scorecard: linking frontline performance to corporate objectives", Management Decision, vol. 34(4), pp. 14-18. 1996.

\section{BIOGRAPHIES OF AUTHORS}
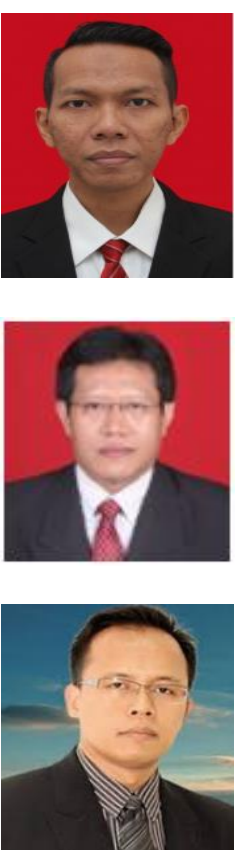

Sunu Sugi Arso, He is graduated bachelor of Information System, from Bina Nusantara University, Jakarta, Indonesia in 1999, and the Master of Information Systems Management degree from Information Systems Management Department, BINUS Graduate Program, Bina Nusantara University, Jakarta, Indonesia. Currently, He worked for PT. PT. Mitra Intergrasi Informatika (MII) Jakarta Indonesia. His research interests include information system, and teleworking.

Sfenrianto Sfenrianto, has received his Ph.D. from Faculty of Computer Science, University of Indonesia, in 2014. Currently, he is a faculty member Information Systems Management Department, BINUS Graduate Program - Master of Information Systems Management, Bina Nusantara University, Jakarta, Indonesia. His research interests include e-Learning, e-Business, e-Commerce, computer education, business intelligence, data mining, and information system.

Mochamad Wahyudi, He is graduate Doctoral in Education Management from State University of Jakarta Indonesia, in 2014. Currently, he is a lecturer and the chairman STMIK Nusa Mandiri Jakarta, Indonesia. His research interests include e-Learning, computer education, and information system. 